\title{
Psychological Component of Credit Scoring: Analysis of Theoretical and Methodical Problems*
}

\author{
Andrey N. Demin \\ Department of Social Psychology and Management \\ Sociology \\ Faculty of Management and Psychology \\ Kuban State University \\ Krasnodar, Russia \\ E-mail: demin@manag.kubsu.ru \\ Igor A. Pomazan \\ Department of Social Psychology and Management \\ Sociology \\ Faculty of Management and Psychology \\ Kuban State University \\ Krasnodar, Russia \\ E-mail: 4632164@mail.ru
}

\author{
Oksana V. Kireyeva \\ Department of Social Psychology and Management \\ Sociology \\ Faculty of Management and Psychology \\ Kuban State University \\ Krasnodar, Russia \\ E-mail: OKSANA-KIREEVA@mail.ru \\ Ekaterina I. Zykova \\ Department of Social Psychology and Management \\ Sociology \\ Faculty of Management and Psychology \\ Kuban State University \\ Krasnodar, Russia \\ E-mail: ev250493@gmail.com
}

\begin{abstract}
The article analyses the importance of using psychological data in credit scoring and presents the data on predictors of timely loan repayments. The problems of using psychological data to credit scoring are highlighted: choosing the way to integrate psychological, social and financial characteristics of a borrower, identifying the weight value of various psychological predictors of loan repayment, gamification of psychological testing, considering the options for immersing respondents in virtual gaming reality during testing, providing feedback to borrowers on their test results, and their financial culture development.
\end{abstract}

Keywords-credit scoring; consumer loan; mortgage loan; gamification; financial culture

\section{INTRODUCTION}

Under modern conditions, there is a growing interest in interdisciplinary approaches to solving current social problems. Thus, when ensuring sustainable functioning of the economic system, psychology of consumers of financial services is becoming increasingly significant. Growing consumer activity results in the rising number of people desiring loans. However, for the banking sector, it is not only providing consumer loans, which is important, but also making profit on loan repayment. Therefore, in the current situation of economic uncertainty and labour and financial markets instability, the issues of strategies and methods for predicting possible financial risks and losses when lending to individuals, is even more acute than before. Economists approach this problem by scoring at the stage of granting

*Fund: The study was carried out with support from the Russian Foundation for Basic Research in the framework of the scientific project No. 18-01301176 A. loans. Scoring is understood as collecting and analysing the information on potential borrowers.

As practice shows, the information on income security of credit customers, collected and recorded within traditional scoring in banking, appears to be insufficient. For this reason, the mandatory information to be collected also includes the data on credit reputation, debt repayment, present debts on other obligations (taxes, utility bills, etc.), and savings.

Even though it requires considerable financial expenses, credit providers are still interested in defining the indicators of borrowers' reliability, which better project the prospects of loan repayment. Focusing on financial information solely is not enough: describing a borrower's experience in the financial market and their available resources, it does not project their future behaviour, especially in stressful or crisis situations. Even with available savings and a high income level, a borrower may deviate from duty and have overdue debts. In this case, their behaviour is predetermined by other factors, both personal (psychological) and situational. Introducing social factors into scoring does not provide the full understanding of regulators of personal financial behaviour either. For instance, a debtor may be aware of the available material resources in people from their social network, but may not ask them for financial support when having financial difficulties. In each particular case, such behaviour can be conditioned by personality traits, interaction with significant others, self-image, as well as other psychological factors.

A number of credit scoring principles require to be reviewed and corrected. For example, according to some of them people having similar property or social indicators are 
- Selecting psychological predictors of loan repayment. The discussion is primarily about the balance between general personal characteristics (for example, general self-efficacy) and special personality traits that directly characterize financial behaviour (for example, financial self-efficacy), and secondly about the weight value of different psychological predictors.

- Psychological scoring should meet the standards of psychometric reliability, validity, and should not be time or effort consuming for a borrower. In this regard, it is necessary to develop not only the content aspect of scoring, but also the procedure for collecting and analysing the information on a borrower. Even though the procedure for obtaining formal financial information and socio-demographic indicators has been well-practiced in banking structures, collecting psychological data is more complicated. Currently, traditional methods of collecting psychological data in the form of written questionnaires are in crisis. First, in traditional testing, potential borrowers tend to give socially desirable answers; second, such questionnaires are negatively perceived. Taking this into account, there is a high demand for new data collection procedures to be developed and introduced, for instance, gamified tests that combine the elements of projective tests and entertainment, thereby eliminating negative aspects of traditional testing.

- When creating gamified tests, it is important to consider the options for immersing respondents in virtual reality and creating situational images different from those of everyday life [6]. This problem is not paid enough attention to, though solving it is directly related to reliability and validity of psychological scoring that applies modern communication and information technologies.

\section{CONCLUSION}

The use of psychological data to credit scoring has an important culture aspect - providing feedback to borrowers on their test results, so that they can correct their financial culture and behaviour. This aspect may be most required when working with potential borrowers, with the youth, in particular. Trying oneself in the role of a borrower in a game situation will contribute to better understanding of the risks and benefits of loans and learning one's strengths and weaknesses as a borrower. Financial socialization and financial culture development are important targets to be achieved through psychological and pedagogical influence. From our perspective, financial culture is an essential part of a modern person's psychological maturity; it implies financial self-control, awareness, independence, reflexivity, and focus on constructive behaviour in the sphere of finance.
- Choosing the way to integrate and identify the weight value of psychological, social and financial characteristics of a borrower in order to calculate the final score.

\section{TheORETICAL AND METHODICAL PROBLEMS OF}

Relevant, yet not fully resolved issues of applying psychological data to credit scoring include the following: 


\section{REFERENCES}

[1] Boyle M., Crook J., Hamilton R., Thomas L. Methods for Credit Scoring Applied to Slow Payers in Credit Scoring and Credit Control. Oxford: Oxford University Press. 1992.

[2] Demin A.N., Kireyeva O.V. Psychological factors of loan repayment // Voprosy Psikhologii. 2018. Issue 3.

[3] Gathergood J. Self-control, financial literacy and consumer overindebtedness // Journal of Economic Psychology. 2012. V. 33(3). DOI: $10.1016 /$ j.joep.2011.11.006

[4] Kamleitner, B., Hoelzl, E., Kirchler, E. Credit use: Psychological perspectives on a multifaceted phenomenon. International Journal of Psychology, 2012, V. 47(1). DOI: 10.1080/00207594.2011.628674

[5] Madera A. G. Projecting the borrower's reliability // Finance and credit. 2013. No. 12.

[6] Zykova E.I., Demin A.N. Kommunikativno-informatsionnye tekhnologii i "chuvstvo real'nosti" [Communication and information technologies and a sense of reality]. Psikhologiya. Istorikokriticheskie obzory i sovremennye issledovaniya [Psychology. Historical-critical Reviews and Current Researches], 2019, V.8. No.1A. DOI: 10.25799/AR.2019.43.1.058

[7] Webley P., Nyhus E. K. Life-cycle and dispositional routes into problem debt // British Journal of Psychology. 2001. V. 92(3). DOI: $10.1348 / 000712601162275$ 